WANL-TME-650

JANUARY 1964

\title{
RELEASE OF FISSION PRODUCTS FROM WANL CAPSULE FP-4
}

(Title Unclassified)

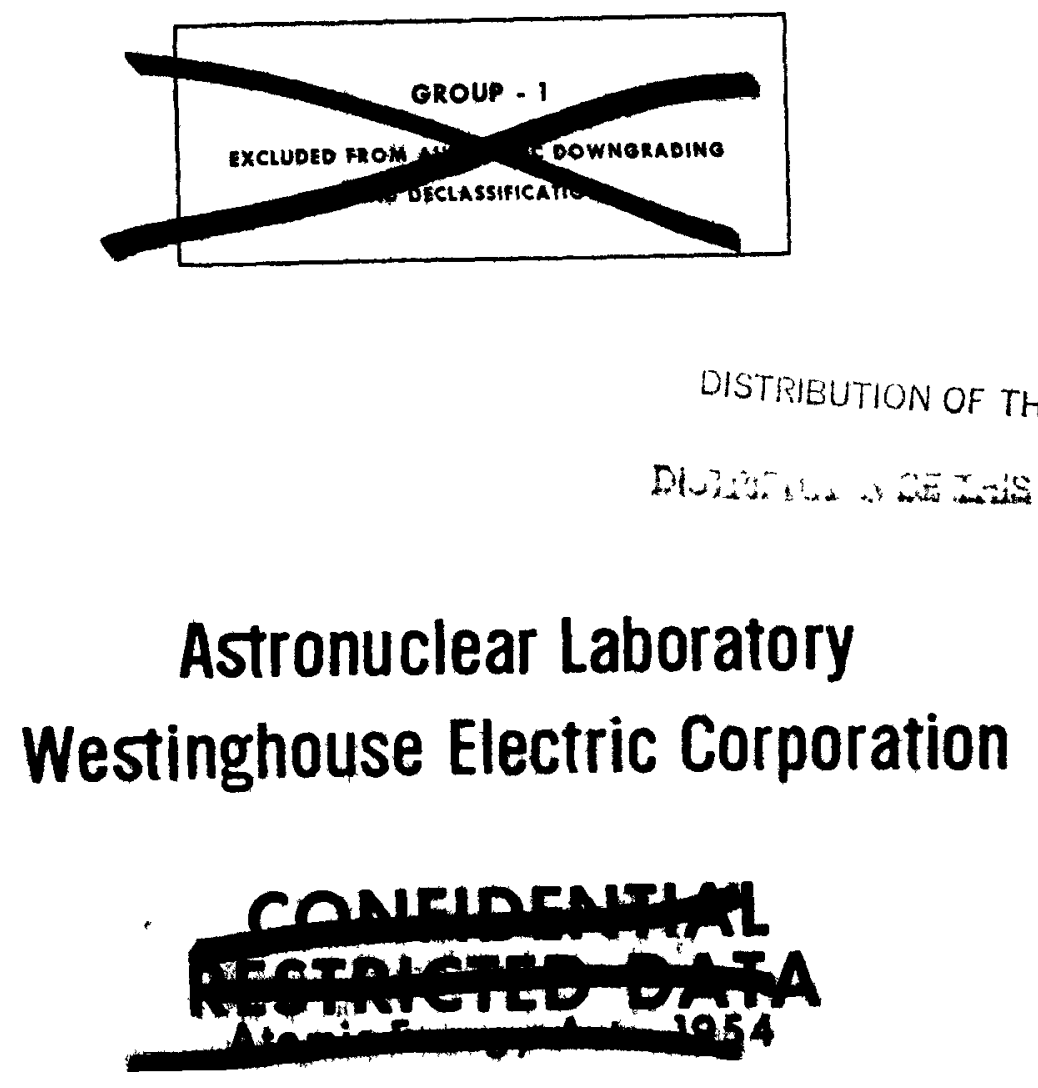




\section{DISCLAIMER}

This report was prepared as an account of work sponsored by an agency of the United States Government. Neither the United States Government nor any agency Thereof, nor any of their employees, makes any warranty, express or implied, or assumes any legal liability or responsibility for the accuracy, completeness, or usefulness of any information, apparatus, product, or process disclosed, or represents that its use would not infringe privately owned rights. Reference herein to any specific commercial product, process, or service by trade name, trademark, manufacturer, or otherwise does not necessarily constitute or imply its endorsement, recommendation, or favoring by the United States Government or any agency thereof. The views and opinions of authors expressed herein do not necessarily state or reflect those of the United States Government or any agency thereof. 


\section{DISCLAIMER}

Portions of this document may be illegible in electronic image products. Images are produced from the best available original document. 
Mr. R. W. Schroeder, Chief Space Nuclear Propulsion Office NASA Lewis Research Center 21000 Brookpark Road Cleveland 35, Ohio

Subject: WANL-TME-650, "Release of Fission Products from WANL Capsule FP-4", dated January 20, 1964

Dear Mr. Schroeder:

Transmitted herewith are three (3) copies of the subject report.

This report is transmitted for your information.

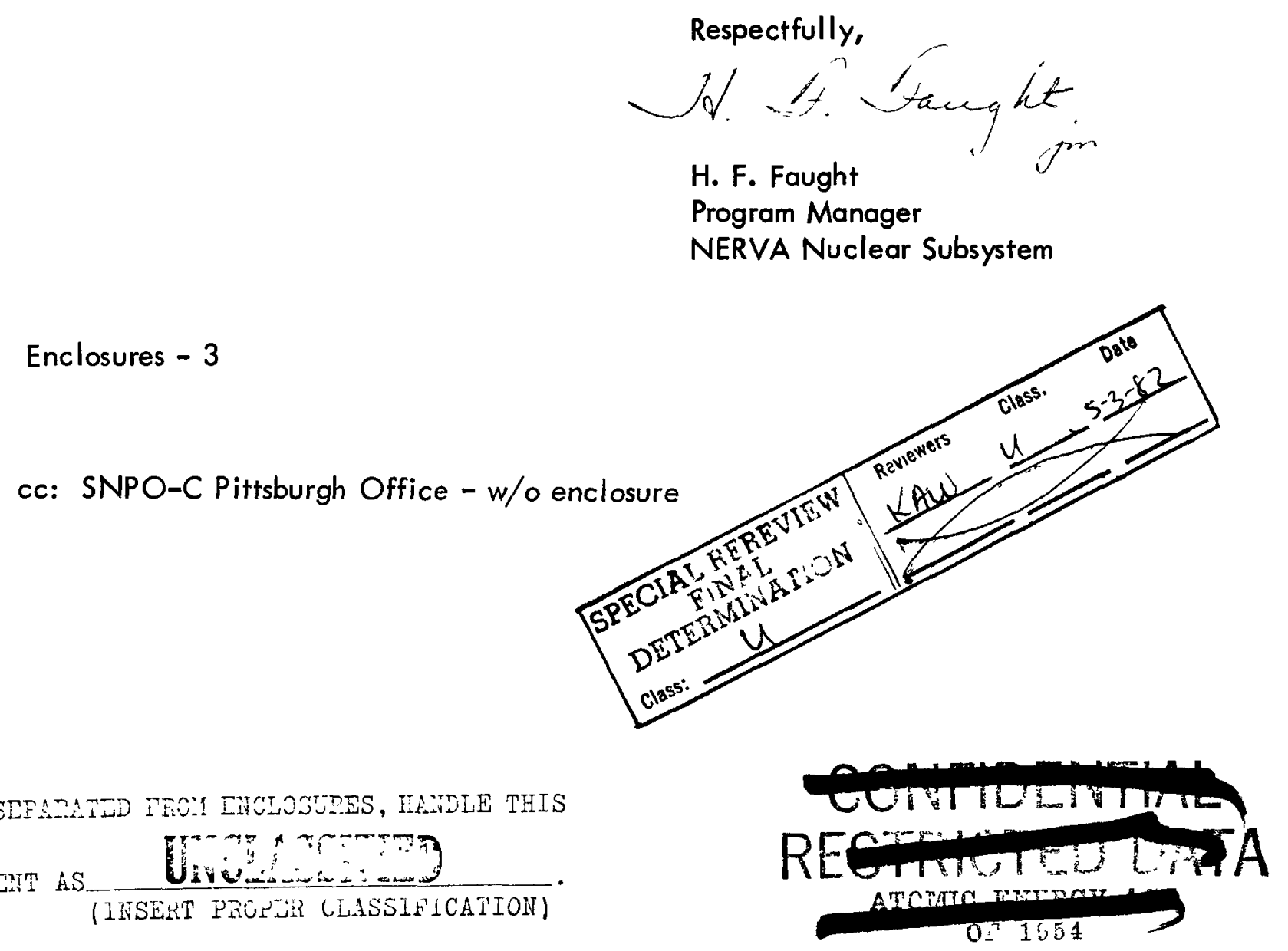




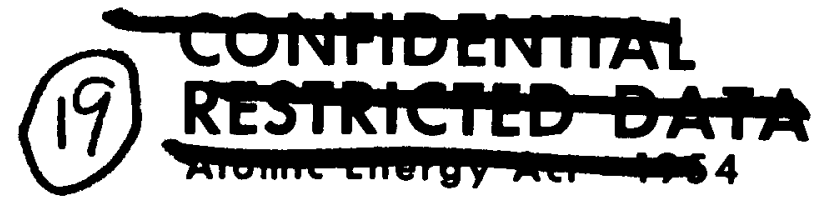

This report was prop NOC

sponsored by the prepared as an account of work the United States United States Government. Neither Research and Development United States Energy their employees, subcontractors, or their of their contractors, warranty, express their employees, makes any liability or responsibility for the or assumes any legal or usefulness of any information accuracy, completeness process disclosed, or represents, apparatus, product or infringe privately owned rights.

\section{Authors}

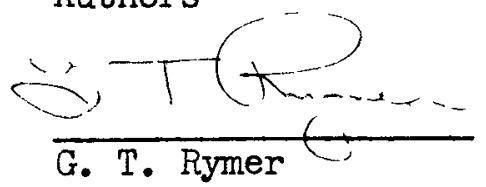

$\frac{\text { W. Henninger } 6}{\text { W. Hen }}$

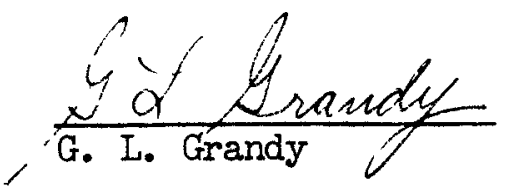

Approval

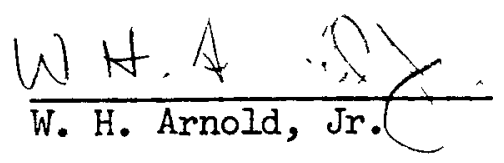

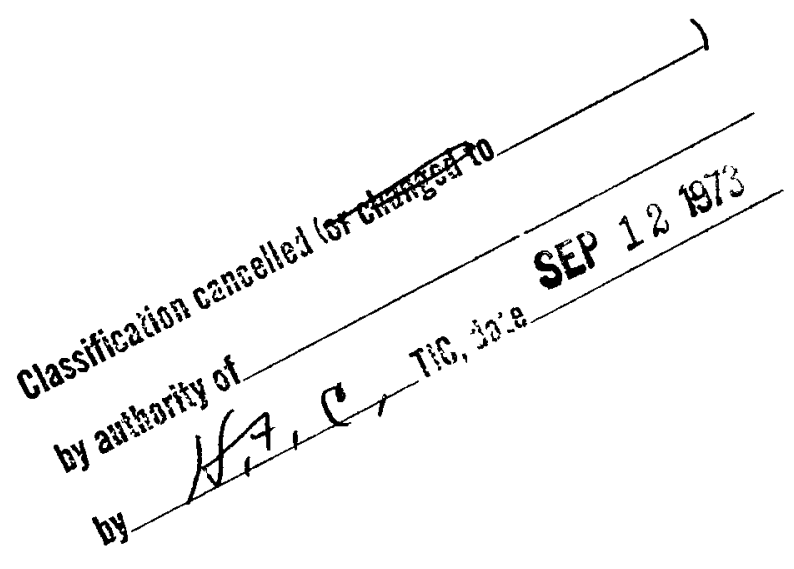
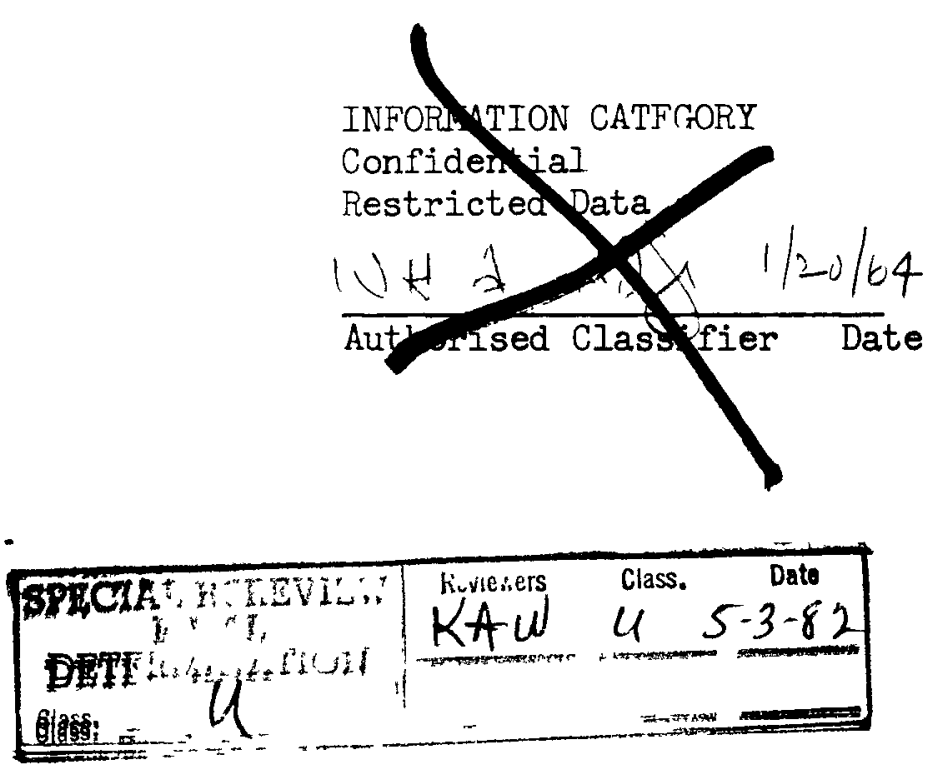
TABLE OF CONTENTS

Section

1.0

2.0

2.1

2.2

2.3

2.4

2.5

3.0

3.1

3.2

3.3

4.0
Title

Introduction

Experimental

Material

Irradiations

Radiochemical Analysis

Post Irradiation Heat Anneal

Calculation of Release Fractions

Results and Discussion

Release during Steady State Irradiation

Release during Post Irradiation Heat Anneal

Release during Transient irradiation in TREAT

Conclusions

Bibliography
Page

1

$I$

1

2

14

16 


\section{Coninguitit

\section{IIST OF TABLES}

Table No.

1

2

3

4

5
Titile

Page

Fractional Release of Fission

Nuclides during irradiation

in GETR

7

Fractional Release of Fission Isotodes During Post Irradiation Heat Anneal

Arrangement of Elements to Boiling

Point and Diffusion Rate

Change in Initial Cross Activity

in NERVA Fuel as a Result of Transient

Fractional Release of Fission Huclides during transient irradiation in TREAT 


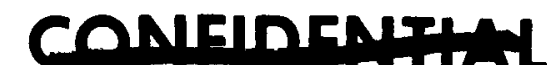

\subsection{INTRODUCTION}

This report describes the release of fission products from type II, beaded NERVA fuel irradiated in capsule WANL FP-4 in conjunction with the fission product diffusion program. The experiments with the fuel samples in this capsule were performed with three main objectives in view:

1. A determination of the fractional release of fission products from the fuel during irradiation at elevated temperatures

2. A determination of the fractional release of fission products during post irradiation heat anneal experiments.

3. A determination of fractional release of fission products during transient irradiations in the TREAT reactor.

The data obtained from post irradiation heat anneals is necessary for determining basic diffusion parameters which can be utilized to formulate a mathematical model which will be incorporated into a modified fission product inventory code. Fractional releases of the various fission products during irradiation will serve to corrobrate release from the operating ractor predicted by the fission product inventory code. Release data obtained during transient irradiations in TREAT will be utilized in predicting the release of fission products during NERVA reactor excursions.

\subsection{EXPERIMENTAL}

\subsection{MATERIAL}

The material used in this study consisted of 12 , cylindrical samples of Type II, beaded NERVA fuel cut from a NERVA B-4 fuel element. As, such, they consisted of $20 \mathrm{Wt} \% \mathrm{UC}_{2}$ in the form of $100 \mathrm{M}$ diameter beads, encased in $25 \mathrm{M}$ 
thick pyrocarbon coat and dispersed throughout a graphite lattice. The $U^{235}$ enrichment of this fuel was 93\%. Sample dimensions at the time of GETR irradiation were $0.25^{\prime \prime}$ long by $0.25^{\prime \prime}$ in diameter with a $0.095^{\prime \prime}$ hole located axially within the cylinder. Prior to the post irradiation heat anneal, the samples were cut in half to yield 24 samples with dimensions $0.25 "$ in diameter by $0.125^{\prime \prime}$ in length.

\subsection{IRRADIATIONS}

Capsule WANL-FP-4 was irradiated on July 2, 1963. Cobalt flux monitor wires located at the top and bottom of the capsule indicated flux levels of $0.995 \times 10^{14}$ and $1.14 \times 10^{14} \mathrm{n} / \mathrm{cm}^{2}-s e c$ in these respective positions during the 15 minute irradiation. A temperature of $2200^{\circ} \mathrm{C}$, as determined by a Tungsten 26\% Rhenium Tungsten thermocouple, was achieved during irradiation. In addition to the GETR irradiation six of the "half" samples were subjected, in pairs, to transient irradiation energies of 177, 451, and 806 megawatt seconds in the TREAT reactor on September 3, 1963. These energies pertain to the TREAT reactor; equivalent NERVA fuel energies would be greater perhaps as much as a factor of twelve. Temperatures achieved during the respective irradiations were 1250,2200 and $\approx 3000^{\circ} \mathrm{C}$. Each irradiation was accomplished in approximately 1 second.

\subsection{RADIOCHEMICAL ANALYSIS}

In order to determine the initial concentration of various isotopes in the twelve samples irradiated in GETR each sample was cut in half, and the half sample dissolved and analyzed for $\mathrm{Sr}^{89}, \mathrm{Ba}^{140}, \mathrm{Ce}^{144}, \mathrm{Y}^{91}, \mathrm{Zr}^{95}$ and $\mathrm{Cs}^{137}$. After TREAT irradiations, analyses were made on the test samples for these nuclides, as well as for $\mathrm{Mo}^{99}$. In addition, gross activity measurements 


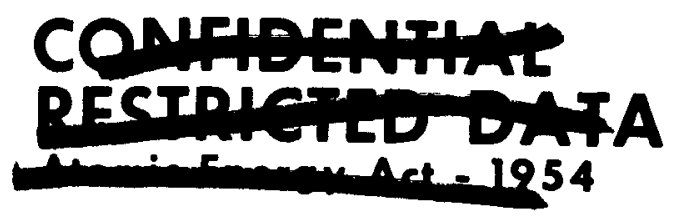

(20)

Lstronuclear

WANL-TME-650

were made on all 24 samples prior wo dissolution of the 12 control samples and a further heating or TREAT irradiation of the test samples.

2.4 POST IRRADIATION HEAT ANNEAL

Four of the test samples which had been irradiated in GETR were heated in an induction vacuum furnace described previously ${ }^{(I)}$ at a temperature of $2000^{\circ} \mathrm{C}$ at time intervals varying from 15 to 60 minutes. All runs were made in a vacuum of $10^{-4} \mathrm{mmHg}$.

\subsection{CALCULATION OF RELFASE FRACTIONS}

In order to determine the fractional release of a nuclide during the various tests it is necessary to know the initial concentration of the nuclide, $C_{0}$, and the concentration of the nuclide after the test, $C_{f}$ with the appropriate decay correction back to the time of the test. The fraction of the nuclide retained is $q_{f} / C_{0}$, and the fraction released is given by the expression $f=1-C f / C_{0}$. Determination of $c f$ is straight forward by radiochemical analysis after sample dissolution. The determination of $C_{0}$ is somewhat more complex and values of $C_{0}$ are determined by different methods according to the particular test performed.

Designating the initial concentration of isotope, $i, c_{G}$, from the GETR irradiation, a value of $C_{G}$ for the post irradiation heat anneal may be obtained by analysis of a control sample irradiated concurrently with the test samples. If the concentration of isotope $i$ in the control sample is $C_{G}^{\prime}$, the gross activity of the control sample as $A_{C}$ and the gross activity of the test sample at $A_{T}, C_{G}$ is found from the simple relationship

$$
C_{G}=C_{G} A_{T} / A_{C}
$$

The determination of the amount of a nuclide, $i$, released during

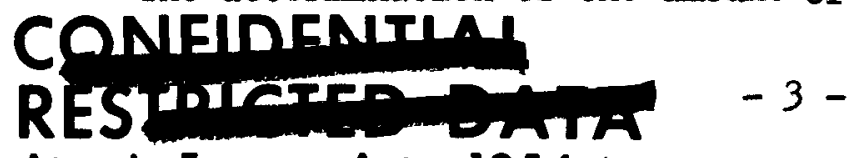


steady state irradiation in GETR requir es a knowledge of the concentration of that isotope formed by the irradiations, $\mathrm{C}_{s}$, and the concentration of that isotope after the irradiation is complete, $\mathrm{C}_{Y} / /$. The value of $\mathrm{C}_{\mathbf{s}}$ is the result of two processes; the direct fission yield, and the decay of the precursors of that isotope. A value of $C_{S}$ for any isotope is easily obtained by the product of the number of fission and the chain Fleld of that isotope. As before, the fraction released during irradiations is $I-c_{f} / C_{s}$ with $C_{s}$ replacing $C_{0}$ in the expression defined above. Is is apparent that the release fraction for a nuclide determined by this method describes release through a mechanism which involves not only the nuclide of interest, but also the precursors to that nuclide. An example of this may by seen by considering the decay chain for $\mathrm{Zr}^{95}$.

$$
\begin{array}{lll}
\mathrm{Br}^{95}-\mathrm{Kr}^{95} \mathrm{Rb}^{95}, \mathrm{Sr}^{95}-\mathrm{y}^{95} \cdot \mathrm{zr}^{95} \cdot \mathrm{Nb}^{95 \mathrm{~m}}-\mathrm{Nb}^{95} \\
0+0.4021+2.1208+2.7711+0.9443+0.018908 \quad=6.257
\end{array}
$$

From this chain yield it may be seen that the direct fission yield of $\mathrm{Zr}^{95}$ is only $0.019 \%$ whereas the total amount of $\mathrm{Zr}^{95}$ and $\mathrm{r}^{99}$ neither of which diffuse readily at the sample temperature $\left(2200^{\circ} \mathrm{C}\right)$ during capsule irradiation. This method was used to determine the loss of fission products from the twelve control samples during the GETR irradiation.

The determination of Co for the samples irradiated in TREAT can be made by combining the two previously described methods. In this case Co $+\mathrm{C}_{\mathrm{G}}+\mathrm{C}_{\mathrm{T}}$. Where $\mathrm{C}_{\mathrm{T}}$ is the original concentration of isotope $i$ formed by the TREAT irradiation. Values of $\mathrm{C}_{\mathrm{T}}$ were obtained by Mo 99 analysis of the test samples after the TREAT irradiation. It should be noted that inorder 
to establish $C_{\mathrm{T}}$ values by this method, precaution must be taken to insure that all Mo 99 from the initial GETR does not contribute to the final analysis of this nuclide. The Mo ${ }^{99}$ contribution from GETR was made negligible by allowing a 23 half life decay time between irradiations. The method of determining the fractional release of a nuclide is perhaps more easily followed by use of the following example. Number of atoms of $\mathrm{Sr}^{89}$ atoms from GETR control sample on September $2=2.05 \times 10^{14}=\mathrm{C}^{\prime} \mathrm{G}$ Gross 8 Activity of control sample $=3.568 \times 10^{5} \mathrm{CPM}=\mathrm{Ac}$ Gross $Y$ Activity of test sample $=3.715 \times 10^{5} \quad \mathrm{CPM}=\mathrm{A}_{\mathrm{T}}$ Hence number of atoms of $\mathrm{Sr}^{89}$ in test sample from GETR irradiation $=\mathrm{CG}$ $=C_{G} A_{T} / A_{C} C_{G} \quad 2.05 \times 10^{4} \times \frac{3.715 \times 10^{5}}{3.568 \times 10^{5}}=2.134 \times 10^{14}$ Number of Mo 99 atoms on September 2 from TREAT irradiation in Test Sample = $4.02 \times 10^{13}$

Fission Yield of $\mathrm{Mo}^{99}=6.06$

Fission Yield of $\mathrm{Sr}^{89} 4.79$

Number of $\mathrm{Sr}^{89}$ atoms on September 2 from TREAT irradiation in test sample $4.02 \times 10^{13} \times \frac{4.79}{6.06}=3.177 \times 10^{13}=\mathrm{C}_{\mathrm{T}}$. The total number of $\mathrm{Sr}^{89}$ atoms formed by both irradiations, $C_{0}=C_{G}+C_{T}=(2.134+0.318) \times 10^{14}=2.452 \times 10^{14}$. Number of $\mathrm{Sr}^{89}$ atoms found in test sample by radiochemical analysis on Sept. 2, $\mathrm{C}=9.930 \times 10^{13}$. Fraction $\mathrm{Sr}^{80}$ retained $=\mathrm{C} / \mathrm{C}_{0}=\frac{9.930 \times 10^{13}}{2.452 \times 10^{14}}=0.405$ and fraction of $\mathrm{Sr}^{89}$ released by TREAT transient irradiation $=1-0.405=0.595$.

\subsection{RESULTS AND DISCUSSION}

\subsection{RELEASE DURING STEADY STATE IRRADIATION}

Values of the fractional release of various nuclides during the GETR

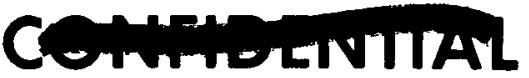


irradiation are given in Table I normalized to Mo99. The concentration of $\mathrm{Mo}^{99}$ was found to be essentially constant from sample to sample validating the premise of no diffusional loss of Mo ${ }^{99}$ or its precursors during irradiation. All other nuclides show substantial losses from the samples located in the center of the capsule. These losses are not surprising in the case of $\mathrm{Sr}^{89}, \mathrm{Ba}^{140}$ and $\mathrm{Cs}^{137}$ which are rapid diffusers, however the losses of $\mathrm{Ce}^{144}, \mathrm{Y}^{91}$ and $\mathrm{Zr}^{95}$ probably occurred via their precursors, since these nuclides do not readily diffuse at the irradiation temperature of $2200^{\circ} \mathrm{C}$. It is interesting to note that release fractions greater than $I$, (negative release fractions) are obtained on the end samples for the nuclides $\mathrm{Sr}^{89}$, $\mathrm{Ce}^{144}$, and $\mathrm{Y}^{91}$. This apparent gain in activity suggests that material diffusing from the central samples redeposits on the end samples. This phenomenon would certainly occur in a static system where diffusing material would transfer from hot to cool zones. The design of the irradiation capsule used for this test conforms to the above description and it is probably a redeposition mechanism rather than a flux gradient which is responsible for the change of activity from sample to sample.

\subsection{RELEASE DURING POST IRRADIATION HEAT ANNEAL}

The fractional release of various nuclides during post irradiation heat anneals at $2000^{\circ} \mathrm{C}$ in vacuum are given in Table 2. Here it may be seen that essentially all of the $\mathrm{Sr}^{89}, \mathrm{Ba}^{140}$ and $\mathrm{Cs}^{137}$ are released in 30 minutes. No release of $\mathrm{Zr}^{95}$ was obtained under these conditions, while $\mathrm{Y}^{91}$ and $\mathrm{Ce}^{1 / 44}$ were somewhat depleted. These data permit arrangement of the various nuclides into four groups, according to their release fraction at $2000^{\circ} \mathrm{C}$ for 30 minutes. 
TABLE I

FRACTIONAL REIEASE OF FISSION NUCLIDES DURING IRRADIATION IN GETR

Sample

Position

89 RT

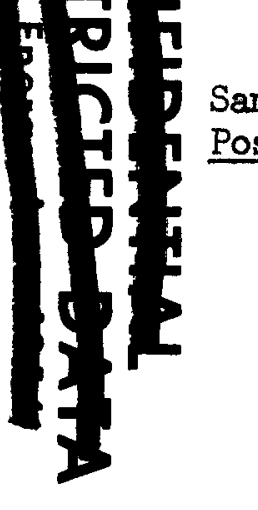

1

2

3

4

5

6

7

8

$\mathrm{Ba}^{140}$

$\mathrm{Sr}^{89}$

$\mathrm{Cs}^{137}$

$C e^{144}$

$\mathrm{r}^{91} \quad \mathrm{zr}^{95}$

0.076

$-0.715$

$-1.08$

0.076

0.787

0.421

0.935

0.550

0.890

0.276

0.976

$0.579 \quad 0.00$

0.758

0.707

0.729

0.975

$\begin{array}{ll}0.512 & 0.00\end{array}$

1

0.951

0.741

0.703

0.846

0.968

$0.511 \quad 0.00$

0.639

0.835

0.948

$0.459 \quad 0.00$

9

0.905

0.640

0.484

0.801

0.874

0.314

0.00

10

0.082

0.480

0.260

0.807

0.783

0.282

0.00

17

0.062

$-0.280$

0.122

$-0.520$

0.764

0.160

0.00

12

0.062

$-0.216$

0.127

$-0.350$

$-1.200$

$0.102 \quad 0.00$




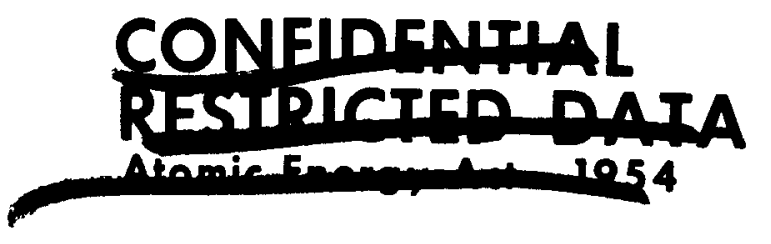

w)

Lstronuclear

WANI-TME 650

$\begin{array}{lll}\text { Group } & \text { P Released } & \text { Nuclide } \\ \text { Group } 1 & >90 \% & \mathrm{Sr}^{89} \mathrm{Ba}^{140} \\ \text { Group 2 } & \langle 90 \%\rangle 70 \% & \mathrm{Cs}^{137} \\ \text { Group 3 } & \langle 70 \%\rangle 10 \% & \mathrm{Y}^{91} \mathrm{C}_{\mathrm{c}}{ }^{141} \\ \text { Group 4 } & \angle 10 \% & \mathrm{Zr}^{95} \mathrm{Mo}^{99}\end{array}$

The relative release rate of these nuclides are in accord with their elemental boiling points. If we assign a range of boiling points of each of the groups it is possible to include elements which represents the majority of the activity after irradiation, but which were not analysed in this study. Such an arrangement is given in Table 3. The elements listed here are comprised of 144 isotopes and represent $96 \%$ of the radioactive species present after a 10 minute NERVA operation. This arrangement is preliminary and justification by determinations of additional nuclides to those presently studied is necessary before release rates can be assigned to all nuclides. The value of such an arrangement however, is the reduction of radiochemistry required to assign diffusion constants to all nuclides over a range of temperature, time or other parameters.

\subsection{RELEASE DURING TRANSIENT IRRADIATION IN TREAT}

The change in gross $/$ activity as a result of the TREAT irradiations are given in Table 4. The gross 8 activities of the test samples measured before the irradiation were corrected to time of irradiation by a decay factor determined from a control sample. Only for the 806 megawatt second irradiation was there any reduction of the initial gross 8 inventory. If the change of gross activity is plotted is a function of irradiation energy, as in Figure $I$,

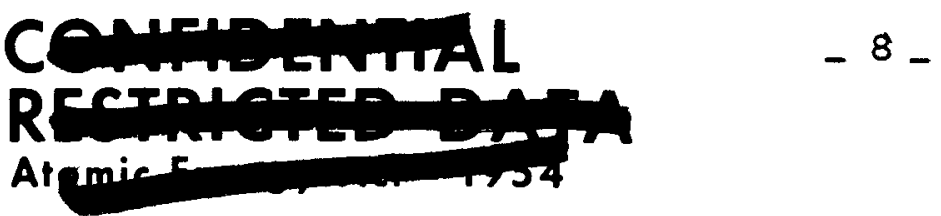


TABIE 2

FRACTIONAL RELEASE OF FISSION ISOTOPES DURING POST IRRADIATION HEAT ANNEAL

\begin{tabular}{llllllll}
$\begin{array}{l}\text { Temperature } \\
\text { (Deg. C.) }\end{array}$ & $\begin{array}{llllll}\text { Time } \\
\text { (Min) }\end{array}$ & $\mathrm{Sr}^{89}$ & $\mathrm{Ba}^{140}$ & $\mathrm{Y}^{91}$ & $\mathrm{Zr}^{95}$ & $\mathrm{Cs}^{137}$ & $\mathrm{Ce}^{144}$ \\
\hline 2000 & 15 & 0.189 & 0.275 & 0.140 & 0.00 & 0.795 & 0.312 \\
2000 & 30 & 0.999 & 0.999 & 0.163 & 0.00 & 0.828 & 0.320 \\
2000 & 45 & 0.999 & 0.999 & 0.218 & 0.00 & 0.823 & 0.334 \\
2000 & 60 & 0.999 & 0.999 & 0.146 & 0.00 & 0.806 & 0.390 \\
\hline
\end{tabular}


TABLE 3

ARRANGEMENT OF EIEMENTS ACCORDING TO BOIIING POINT AND DIFFUSION RATE

Boiling Point Range (Deg. C.)

1. $\mathrm{Rb}, \mathrm{Sr}, \mathrm{Kr}, \mathrm{Ba}, \mathrm{Br}, \mathrm{Xe}, \mathrm{I}$, Se, As -153 to 1200

2. $\mathrm{Sb}, \mathrm{Ta}, \mathrm{Cs}$

3. Y, Ia, Ce, Sn, Ru, Rh

4. $\mathrm{Nb}, \mathrm{Zr}, \mathrm{Mo}$
1200 to 1400

1400 to 2900

2900 to 3700 Release $90 \%$

$90 \%$

$70 \% 10 \%$

$10 \%$

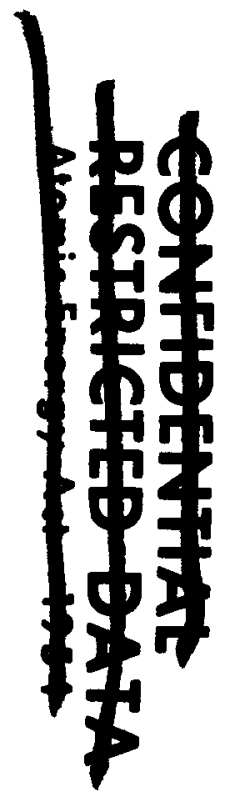

5 
TABLE 4

CHANGE IN INITIAL GROSS iCTIVITY IN NERVA FUEL AS A RESULT OF TRANSIENT

IRRADIATION IN TREAT

\begin{tabular}{clllll}
$\begin{array}{c}\text { Sample } \\
\text { Number }\end{array}$ & $\begin{array}{l}\text { Energy } \\
\text { Transient } \\
\text { (Megawatt } \\
\text { seconds) }\end{array}$ & $\begin{array}{l}\text { Namber } \\
\text { of Fissions }(1)\end{array}$ & $\begin{array}{l}\text { Weight } \\
\text { Loss } \\
(\not)\end{array}$ & $\begin{array}{l}\text { Change in } \\
\text { Gross Activity } \\
(\%)\end{array}$ & $\begin{array}{c}\text { Average Change } \\
\text { in Gross Activity } \\
(\%)\end{array}$ \\
\hline 1 & 177 & $1.57 \times 10^{13}$ & 0.0 & +5.35 & +4.18 \\
2 & 177 & $1.55 \times 10^{13}$ & 0.0 & +3.01 & +11.69 \\
3 & 451 & $4.13 \times 10^{13}$ & 0.0 & +11.69 & +11.69 \\
4 & 451 & $4.07 \times 10^{13}$ & 0.0 & -6.35 & -6.40 \\
5 & 806 & $6.34 \times 10^{13}$ & 12.8 & -6.45 & \\
6 & 806 & $6.56 \times 10^{13}$ & 10.8 & & \\
\hline
\end{tabular}

(1) Determined by a Mo99 analysis 
(20)/ 1 stronuclear

WANL-TME-650

\section{FIGURE I}

CHANGE IN GROSS ACTIVITY, OF NERVA SAMPLES IRRADIATED IN TREAT
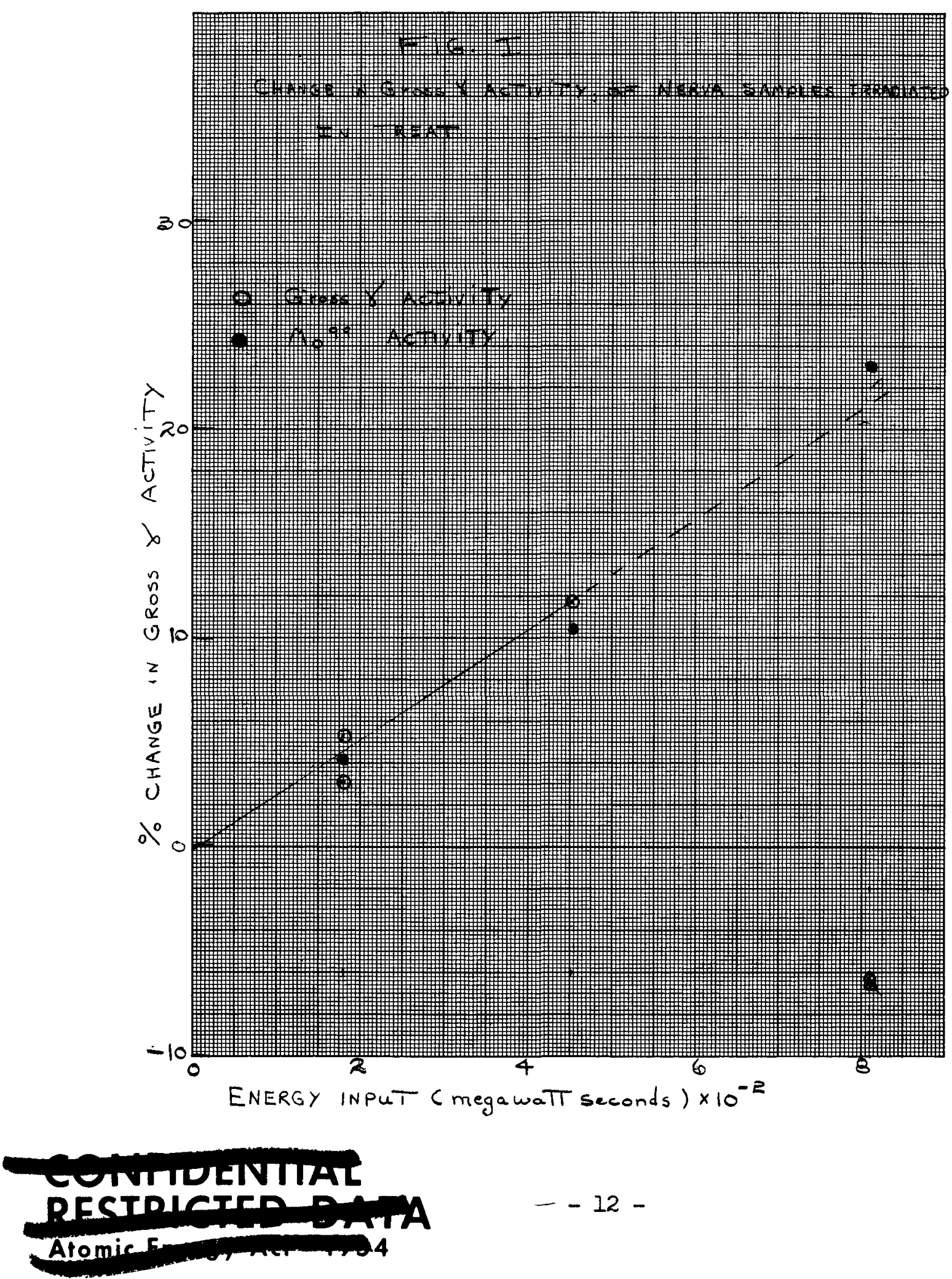
TABLE 5

FRACTIONAL REIEASE OF FISSION NUCIIDES DURING TRANSIENT RRADIATION IN TREAT

\begin{tabular}{llllllll}
$\begin{array}{l}\text { TREAT Transient } \\
\text { Irradiation energy } \\
\text { megawatt seconds }\end{array}$ & $\begin{array}{l}\text { Temperature } \\
\text { (Deg. C) }\end{array}$ & $\mathrm{Ba}^{140}$ & $\mathrm{Sr}$ & $\mathrm{Cs}^{137}$ & $\mathrm{zr}^{95}$ & $\mathrm{Y}^{91}$ \\
\hline 177 & 1250 & 0.084 & 0.005 & 0.0175 & 0.00 & 0.00 & 0.00 \\
451 & 2200 & 0.164 & 0.109 & 0.0180 & 0.086 & 0.00 & 0.00 \\
806 & 0.558 & 0.595 & 0.619 & 0.086 & 0.00 & 0.187 \\
\hline
\end{tabular}

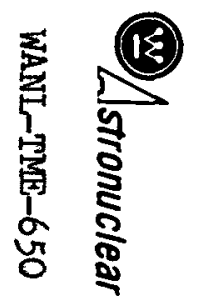


an activity increase of $21 \%$ at 806 MWS would be predicted by linear extrapolation. Some justification for this linear extrapolation is given by the values obtained for Mo99 concentration which has been normalized to the gross 8 activity and included in Figure $I$.

Release fractions for the various nuclides comprising the initial inventory from the GETR irradiation are given in Table 5. Small losses of $\mathrm{Ba}^{140}, \mathrm{Sr}^{89}$ and $\mathrm{Cs}^{137}$ occured during the 177 and $451 \mathrm{MW}$ 's irradiations, with no loss of $\mathrm{Zr}^{95}, \mathrm{Y}^{91}$ and $\mathrm{Ce}^{144}$. During the $806 \mathrm{MW}$ 's irradiation there was release of all nuclides for which an analysis was made with the exception of $\mathrm{Y}^{91}$. The losses for $\mathrm{Sr}^{89}, \mathrm{Ba}^{140}$ and $\mathrm{Cs}^{137}$ are substantial amounting to approximately $50 \%$ for each of the three nuclides. The $50 \%$ losses obtained for these nuclides are not adequately reflected in the $6 \%$ gross 8 activity loss, for the obvious reason that the activity represents only a small portion of the total activity present. Calculation of the fission product inventory after 62 days decay, (2) the time lapse between GETR and TREAT irradiations) shows the percentage contribution to the total activity by the elements $\mathrm{Ba}, \mathrm{Sr}$, and $\mathrm{Cs}$, is $13.7 \%$. A $50 \%$ reduction of these elements would constitute only a $6.9 \%$ reduction in gross activity which is in qualitative agreement with the $6.4 \%$ value obtained for gross 8 activity.

\subsection{CONCLUSIONS:}

1. Substantial release of $\mathrm{Ba}^{140}, \mathrm{Sr}^{89}, \mathrm{Cs}^{137}, \mathrm{Ce}^{144}, \mathrm{Y}^{91}$ and $\mathrm{Zr}^{95}$ occur during irradiation of NERVA fuel in GETR at $2200^{\circ} \mathrm{C}$.

2. The release of these nuclides is the net result of diffusion of both the nuclides and their precursors.

3. Greater than $90 \%$ release of $\mathrm{Sr}^{89}, \mathrm{Ba}^{140}$ and $\mathrm{Cs}^{137}$ is obtained from NERVA

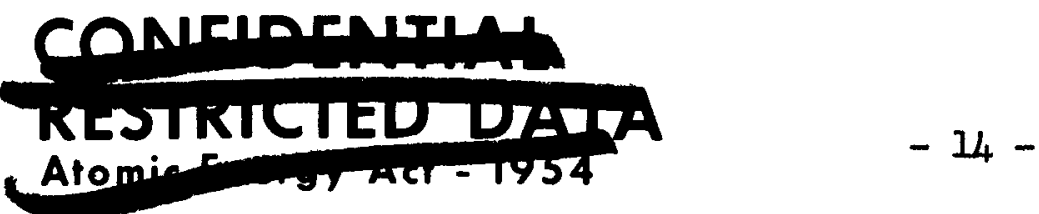


fuel heated to $2000^{\circ} \mathrm{C}$ in vacuum for 30 minutes.

4. No release of $\mathrm{Zr}^{95}$ and $\mathrm{Mo}^{99}$ occurs during post irradiation heating $2000^{\circ} \mathrm{C}$ over a 60 minute interval.

5. The relative release order of the nuclides studied are $\mathrm{Ba}^{140}, \mathrm{Sr}^{89}$, $\mathrm{Cs}^{137}, \mathrm{Ce}^{144}, \mathrm{Y}^{91}, \mathrm{Zr}^{95}$ and $\mathrm{Mo}^{99}$. This corresponds to the same order obtained when these elements are arranged according to their boiling points.

6. Transient irradiations at 177 and 451 megawatt second TREAT energies, increase the inventory in pre-irradiated NERVA fuel.

7. A transient irradiation of 800 megawatt seconds the original inventory by less than $10 \%$.

8. The majority of the loss of inventory is due to the dedustse of $\mathrm{Ba}, \mathrm{Cs}$, $\mathrm{Sr}$ and Ce isotopes

9. There is negligible loss of $\mathrm{Y}, \mathrm{Zr}$, and Mo during transient of 800 megawatt seconds or less. 


\section{BIBLIOGRAPHY}

1. The release of Fission Products from UC 2 Graphite Fuels. WANI-TME 542, Sept. 1963, G. T. Rymer, W. A. Henninger, G. L. Grandy

2. Calculated Activities and Abundances of $\mathrm{U}_{235}$ Fission Products $\mathrm{R}$. C. Boles and N. E. Boles Nuclear Science and Engineering 5 156-185 (1959) 